\title{
DNA barcoding of fishes from River Song, Dehradun, Uttarakhand using mitochondrial cytochrome-c oxidase-I gene.
}

\author{
Madhu Thapliyal ${ }^{1}$, Bipin Kumar Sati ${ }^{2}$, Ravi Kumar ${ }^{2}$, Tribhuwan Chandra ${ }^{2}$ and Ashish \\ Thapliyal $^{2} \bowtie$
}

Received: 21.08.2013

Accepted: 19.11.2013

\begin{abstract}
The entire Himalayan region is well known as a global hotspot for biodiversity. Many workers have documented different aspect of biodiversity. The Uttarakhand Himalaya region, a part of Himalayan system, is very rich in fresh water aquatic biodiversity because it has many fresh water streams and rivers within a short distance of 200 miles. All these fresh water bodies harbor diverse aquatic fauna with fishes being the most extensively studied. There are many fish species reported by many authors in Uttarakhand. Many of the fishes have similar morphological characters (morpho-metrics) and are difficult to identify. Attempts have been made to generate the DNA barcode of fishes but most of the attempt are limited to major rivers i.e. the Ganges and the Yamuna. Besides these two prominent river (the Ganges \& the Yamuna), there are many supporting streams and small tributaries that are also inhabited by many species. No "long term" and "entire river scan" for fish species has ever been conducted in Uttarakhand. Our research aims to generate a molecular database (DNA Barcode) for entire fish species fauna in each small river/stream of Uttarakhand. Using a combination of morphometric \& DNA bar-coding data will provide an efficient method for species level identification and contributes considerably to taxonomic and biodiversity research. The present study is first step towards establishing molecular taxonomy database of Uttarakhand based upon the bar coding pattern of cytochrome c oxidase I (COI) gene. We carried out an "entire river scan" of River Song (a tributary of river Ganges). 50 samples were collected from various sampling sites along the entire stretch of river and analyzed. Data was uploaded into the BOLD database and the analysis of data using this database suggests that the genetic variability (K2P distance) distribution of 50 individuals belonging with 15 species.The average intraspecific variation using $\mathrm{K} 2 \mathrm{P}$ and $\mathrm{NJ}$ methods/models was assessed. The mean intraspecific distance was less than $1.45 \%$ for $32 \%$ of species. Mean K2P distance within species, genus and family was $0.1 \%, 16.3 \%$ and $21.70 \%$ respectively. Our results suggest that River Song has diverse fish fauna with substantial genetic diversity. Data from Barillius species suggests that this species has a very high variation. There is ahighly probability that as all the rivers are scanned new data on endemic and exotic fish fauna diversity will emerge which would be helpful in conservation efforts.
\end{abstract}

Keyword: bar-coding, species identification, fresh water fishes, biodiversity, molecular taxonomy

\section{Introduction}

Classifying animals and plants is one of the world's oldest professions. Accurate identification of species is crucial for research, other areas of biology and biodiversity conservation (Diwaker and Balakrishnan, 2007, Pfenninger, et al. 2007, Lumbsch et al. 2011). Estimating the number of species in a community is a classical problem in ecology, biogeography and conservation biology. Till recently only morpho-metrics/morphologywas the criteria for classification. But, it was discovered that some individuals that look similar but are genetically different and are a separate species altogether. Hence a new initiative was

\section{Author's Address}

${ }^{1}$ Pt. Lalit Mohan Sharma P.G. College, Rishikesh, Uttarakhand, ${ }^{2}$ Graphic Era University, 566/6, Bell Road, Clement town, Dehradun, Uttarakhand, India

Email: ashish.thapliyal@gmail.com launched i.e. to develop database that uses a combination of both approaches-collection and molecular identification. Thus specimen collections, their digitization and developing bioinformatics based databases are becoming vital and many barcoding initiatives are ongoing world over (Chakrabarty 2010, Pyke and Ehrlich 2010).

Use of molecular biological techniques started with protein electrophoresis on starch about 45 years ago (Manwell and Baker 1963), followed by the study of allozymes (Aron and Sole-Cava 1991, Gusma et al. 2000), restriction fragment length polymorphism (RFLP) (Moyse's and Almeida-Toledo 2002), DNA arrays (Hajibabei et al. 2007), single nucleotide polymorphism (Shaffer and Thonsom, 2007), multiplex PCR (Mendonca et al. 2009), DNA sequences (Pook and McEwing 2005, Lemer et al. 2007) and many others. Parallel to all these 
studies Hebert et al. 2003 proposed the use of a small fragment of approximately 652 bases from the 5' end of the mitochondrial cytochrome c oxidase subunit I (COI) gene can be a universal standard to identify most species of animals based on which various studies were carried out world over (Hebert et al. 2003). After this discovery that, especially in animals, a specific region of COI gene is species specific, it has become a universal standard.

Uttarakhand Himalaya region, a part of Himalayan system, is very rich in fresh water aquatic biodiversity because it has many fresh water streams and rivers within a short distance of 200 miles. All these fresh water bodies harbor diverse aquatic fauna with fishes being the most extensively studied. There are many fish species reported by many authors in Uttarakhand. Many of the fishes have similar morphological characters (morpho-metrics) and are difficult to identify.This has already been reported in the case of Schizothorax (richardsonii and plagistomas). Attempts have been made to generate the DNA barcode of fishes but most of the attempt are limited to major rivers i.e. the Ganges and the Yamuna. Besides these two prominent river (the

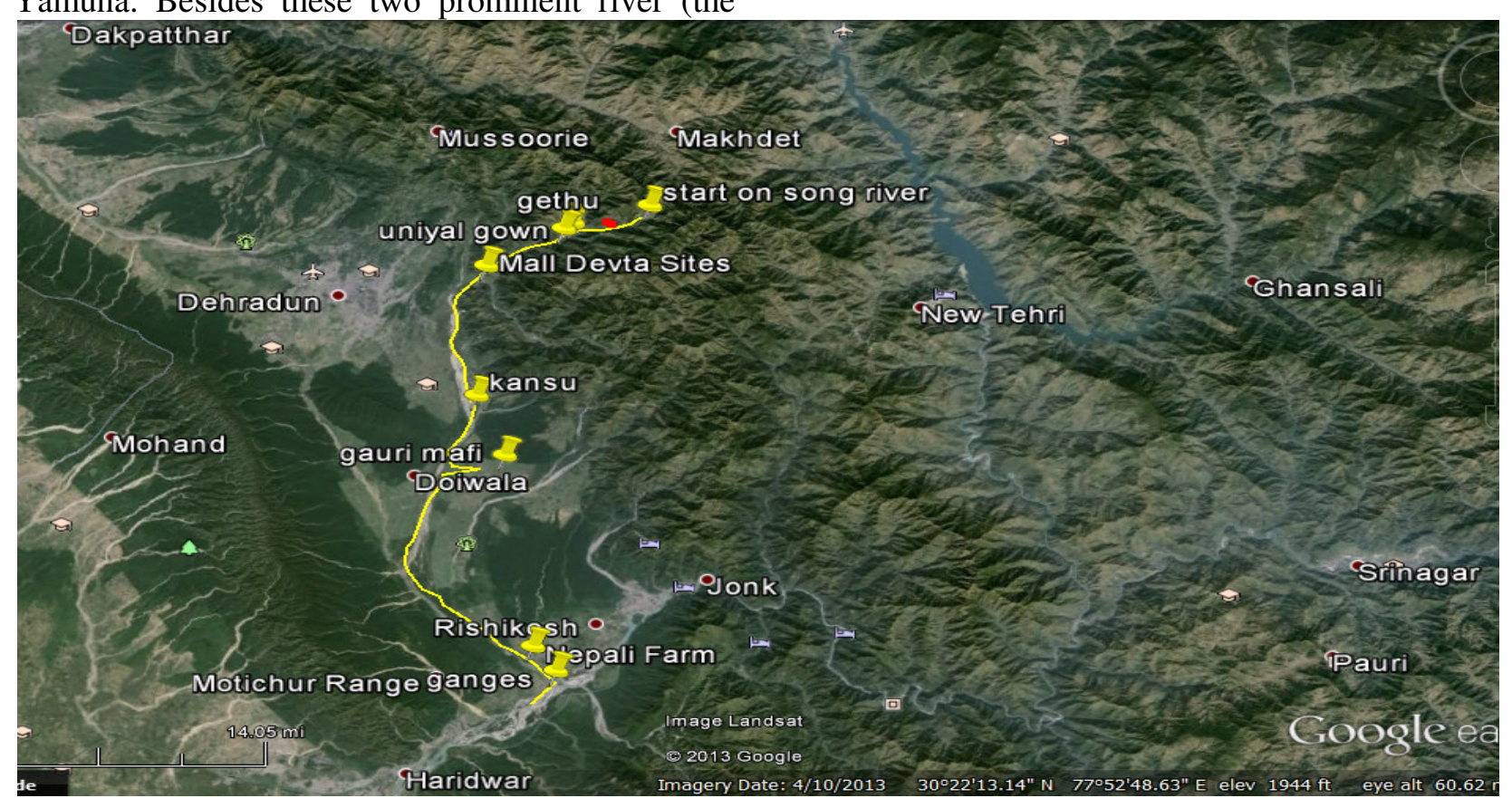

Figure 1: Location of sampling station.River song originates at Uniyal Gaon (Village) and after flowing through Mal Devta, Gauri Mafi, Kansu, Doiwala, it merges into the Ganges at Nepali farm (located near Rishikesh). Seven sampling station are shown in the map. (Made in Google earth)
Ganges \& the Yamuna), there are many other also inhabited by many species. No "long term" and "entire river scan" for fish species has ever been conducted in Uttarakhand. Our research aims to generate a molecular database (DNA Barcode) for entire fish species fauna in each small river/stream of Uttarakhand and develop a molecular database. This data will also help in assessment of genetic diversity by adding some more experiment to current dataset.

\section{Material and methods}

Study site: The present study performed an "entire river scan" of River Song. Song River originates at the base of Himalaya near Mussoorie (around Uniyal Gaon) in Garhwal region of $\left(30.18^{0} \mathrm{~N}\right.$; $78.14^{0} \mathrm{E}$ and altitude 3794 feet - Fig. 1), Uttarakhand. After covering a distance of 140 kilometers (approximately), the Song River (a tributary of Ganges) merges into the Ganges River at Gohri Mafi, Dehradun (near Rishikesh - $30.01^{0} \mathrm{~N} ; 78.14^{0} \mathrm{E}$ and altitude (1024 feet). supporting streams and small tributaries that are 
50 fishes were collected from seven different sites in the song river basin (Figure 1). Fishes were sampled mainly from the medium course of the song river ranging from headwater to floodplains.Sampling stations were $20 \mathrm{~km}$ apart and a total of 7 such stations (one station was rendered inaccessible) were sampled with nets of different mesh size. Sampling was repetitive and during different seasons also - so as to get maximum fish catch (as per requirement of BOLD data). From the collected sample specimens, tissue samples were cut (a piece of pectoral fin) and preserved in 95\% ethanol and the specimens were preserved in formalin for morphological analysis.
A voucher ID was assigned to each specimen. voucher specimens were accessioned in to collection of the Department of Zoology R.C.U Government PG College, Uttarkashi, Uttarakhand, India. Fishes were individually collected and photographed with their all taxonomical characters exposed (along with a measuring scale and a colour coding strip -Table 1). The original fish and the sampled tissue were tagged similarly and the sampled tissues were preserved at $-20^{\circ} \mathrm{C}$ freeze. The morphological data of these fishes was then uploaded to BOLD project entitled "The Song River fish barcoding, India” SRFBI (http://www.boldsystems.org).

Table1: Sample of data sheet for DNA barcoding as per BOLD database. Each sample was placed adjacent to a colour coded strip and a measuring scale and then photographed. Each sample was then preserved as per BOLD database requirements.

\begin{tabular}{|c|c|c|c|}
\hline & Species & Sample location & Photo \\
\hline 1 & Barilius barna & MALLDEVTA & 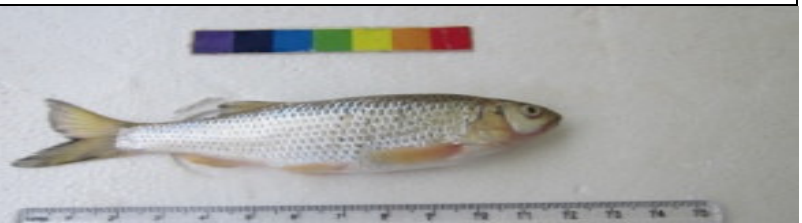 \\
\hline 2 & $\begin{array}{l}\text { Barilius } \\
\text { bendelisis }\end{array}$ & MALLDEVTA & 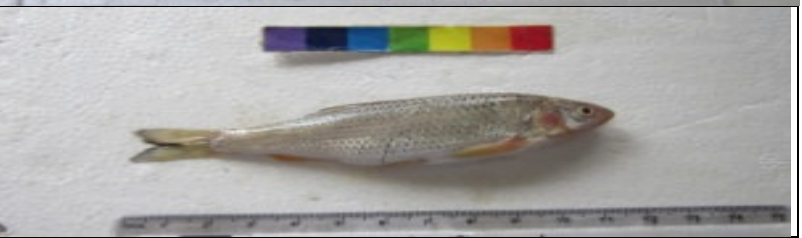 \\
\hline 3 & Barilius tileo & MALLDEVTA & 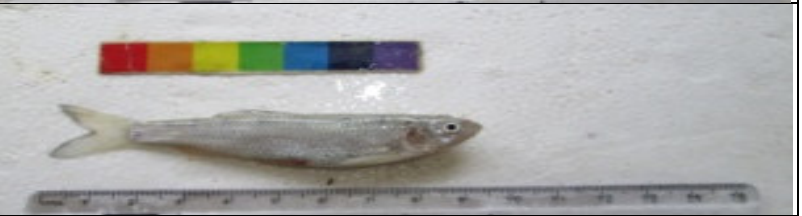 \\
\hline 4 & $\begin{array}{l}\text { Chagunius } \\
\text { cnagunio }\end{array}$ & NEPALI FARM & 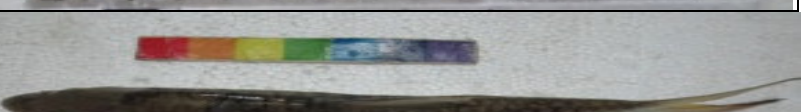 \\
\hline 5 & $\begin{array}{l}\text { Garra gotyla } \\
\text { gotyla }\end{array}$ & GORIMAFI & nang \\
\hline 6 & Garra oatyla & CODIMAEI & 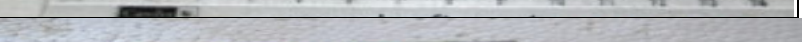 \\
\hline 0 & Garra gotyla & GORIMAFI & $-2=$ \\
\hline
\end{tabular}


DNA extraction, PCR amplification and sequencing: The DNA of the sampled tissues was then isolated by Wizard Genomic DNA Purification Kit (Qiagen Integrity Cat\# A1120). The isolated DNAs was then checked on $1 \%$ agarose gel. Quantity of isolated DNA was checked on Nano-drop 1000 spectrophotometer (Applied bio-system, USA) at absorbance values of 260 and $280 \mathrm{~nm}$.

Table 2: Thermal cycler program for PCR of COI gene in freshwater fishes

\begin{tabular}{|l|ccc|}
\hline Process & Temperature & Time & Cycles \\
\hline Initials denaturation & $95^{\circ} \mathrm{C}$ & 5 MINUTE & 1 CYCLE \\
Denaturation & $95^{\circ} \mathrm{C}$ & 30 SECONDS & 35 CYCLE \\
Annealing & $55^{\circ} \mathrm{C}$ & 30 SECONDS & \\
Extension & $72^{0} \mathrm{C}$ & 1 MINUTE & \\
Final Extension & $72^{0} \mathrm{C}$ & 7 MINUTE & ONE CYCLE \\
\hline
\end{tabular}

After PCR, the samples were then run at $1.5 \%$ of agarose gel for their quality check (Fig. 2). The sample showing one clear band after PCR samples were sorted and purified with EXO1-SAP (Exonuclease1 and shrimp alkaline phosphatase: USB Corp - this step removes excess of dNTP's, Taq polymerase and buffer components from PCR samples) with the temperature conditions suggested by manufacturer. The purified PCR amplicons were then labeled with big dye terminator v3.1 (Applied Bio systems) by cycle sequencing with each side labelled separately. The cycle sequencing PCR reaction contained ready reaction mix $(2.5 \mathrm{x}) 0.5 \mu \mathrm{L}$, dilution buffer $1.75 \mu \mathrm{L}$, template $200 \mathrm{ug} / \mu \mathrm{L}$ and $1 \mu \mathrm{L}$ primer $(0.8 \mathrm{pMol} / \mu \mathrm{L})$. The cycle sequenced amplicons were then purified with big dye (R) X terminator (TM)(Big dye terminator v 3.1 clean up applied bio systems, USA) each side labelled separately and was then sequenced on ABI 3130 DNA genetic analyzer with $2 \mu \mathrm{L}$ of purified sample and $4.75 \mu \mathrm{L}$ of MQ water. The cycle sequencing conditions was initial denaturation of $96^{\circ} \mathrm{C}$ for $1 \mathrm{~min}$ followed by 35 cycles of denaturation $96^{\circ} \mathrm{C}$ for $10 \mathrm{sec}$, annealing $50^{\circ} \mathrm{C}$ for $5 \mathrm{sec}$, extension $60^{\circ} \mathrm{C}$ for $4 \mathrm{~min}$ and then the samples were stored at storage temperature of $4^{0} \mathrm{C}$. The sequences were then obtained and analysed in the Sequence Scape software v2.7 for possibilities of indels (Applied bio systems 3130 genetic analyzers). The names of fishes, collection codes, photographs, sequences, trace files were then uploaded to BOLDs project "The Song River fish bar-coding, India" SRFBI. The obtained sequences were also submitted to NCBI Gene Bank for accession numbers.

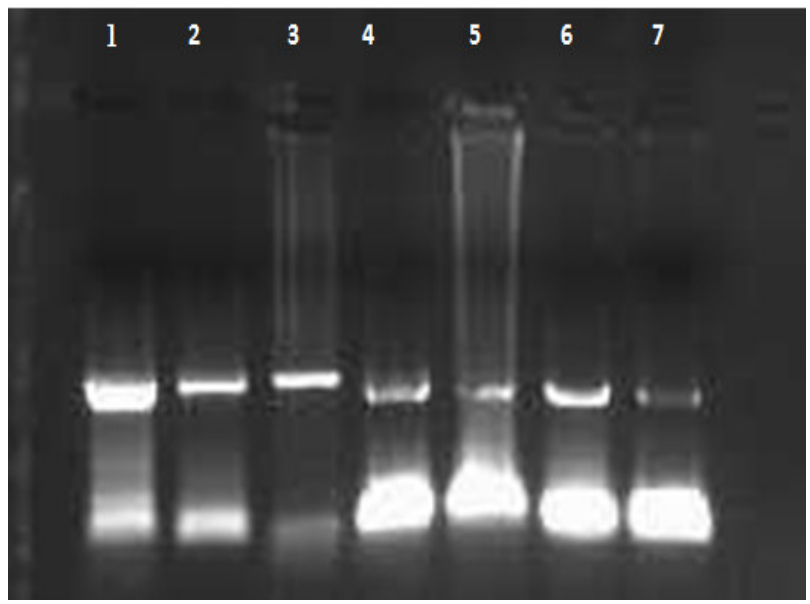

Figure 2: COI mitochondrial genes PCR amplified products. (PCR sample loaded in Gel. The sample id of each well is as follows: 1- Barilius barna, 2Barilius bendelisis,3- Barilius tileo,4- Chagunius cnagunio,5- Garra gotyla gotyla, 6-Garra gotyla and 7- Barilius barna. The first band is COI amplicon and the last band (running in front) is primer dimer. 


\section{Data analysis}

Song River data sequences were edited and aligned using codon code aligner (v5.6; codon code crop USA). All data (i.e. electro-pherograms, trace files, primer details, photograph and collection localities) for each specimen were deposited within the project song river fresh water fishes-the song basin population file on BOLD (http://www.boldsystems.org) and the assembled DNA sequence were also submitted to Gene bank (accession numbers included in appendix online tools implemented on BOLD were used to estimate pair wise sequence divergences using the kimura two-parameter (K2P)distance model, as well as to calculate nearest -neighbour distance (NND) values and neight bo-joining phonograms.

\section{Results and Discussion}

A total 15 species from fifty samples belonging to 02 families were sampled and barcoded under the "Song River Scan" program and uploaded into the "SRFBI" project on BOLD. The COI sequence obtained was high quality and the subsequent counting assemblies generated. A total of $32 \mathrm{COI}$ barcode were obtained from fifty specimens in two families, constituting around $50 \%$ of all know fauna of the song river. All amplified sequences were large then $600 \mathrm{bp}$ and no insertions, deletions or stop codons were observed hence reducing the possibility of nuclear DNA. This also confirmed that the sequence originated from mitochondrial DNA. Accession numbers were granted by NCBI and were uploaded into the BOLD SYSTEM only one species failed to sequencing. Accession number to BOLD and Gene bank sequences for each specimen are provided (Table 3). All species were discriminated by the barcode sequences. A complete NJ tree of entire data is presented in figure 3. This was made by the entire dataset uploaded into BOLD Database. The average K2P distance of specimens within species was $0.61 \%$ as compared to within genus which was $16.3 \%$. Within family, the mean distance was $21.79 \%$ for species with genera (Table 4). The overall variation was about 30 times (approximately) lower among the congeneric species as compared to within species. (Figure 5).
Table 3: NCBI Gene bank accession number for sequences generated during the study. Names and their corresponding accession number is mentioned in the table.

\begin{tabular}{|c|c|c|}
\hline $\begin{array}{l}\text { S } \\
\text { No }\end{array}$ & Species name & $\begin{array}{c}\text { Genbank } \\
\text { Accession no }\end{array}$ \\
\hline 1 & Barilius barna & JN965191 \\
\hline 2 & Barilius barna & JN965190 \\
\hline 3 & Barilius bendelisis & JN965192 \\
\hline 4 & Barilius bendelisis & JN965196 \\
\hline 5 & Barilius bendelisis & JN965195 \\
\hline 6 & Barilius bendelisis & JN965194 \\
\hline 7 & Barilius bendelisis & JN965204 \\
\hline 8 & Barilius bendelisis & JN965212 \\
\hline 9 & Barilius bendelisis & JN965193 \\
\hline 10 & Barilius tileo & JN965198 \\
\hline 11 & Barilius tileo & JQ692874 \\
\hline 12 & Chagunius chagunio & JN965199 \\
\hline 13 & Garra gotyla & JN965210 \\
\hline 14 & Garra gotyla & JN965211 \\
\hline 15 & Garra gotyla & KC473939 \\
\hline 16 & Garra gotyla gotyla & \\
\hline 17 & Macrognathus pancalus & $\underline{\mathrm{KC} 473940}$ \\
\hline 18 & Puntius conchonius & JN965201 \\
\hline 19 & Puntius ticto & JN965202 \\
\hline 20 & Puntius ticto & JN965203 \\
\hline 21 & Schizothorax progastus & JN965205 \\
\hline 22 & Schizothorax progastus & $\underline{\text { JQ692872 }}$ \\
\hline 23 & Schizothorax progastus & JQ692870 \\
\hline 24 & Schizothorax progastus & $\underline{\text { JQ692873 }}$ \\
\hline 25 & Schizothorax sp. & $\underline{\mathrm{JQ692871}}$ \\
\hline 26 & Torchelynoides & JN965207 \\
\hline 27 & Tor chelynoides & JN965206 \\
\hline 28 & Tor putitora & JN965209 \\
\hline 29 & Tor putitora & JN965197 \\
\hline 30 & Tor sp. & KC473941 \\
\hline 31 & Tor tor & KC473942 \\
\hline 32 & Tor tor & JN965208 \\
\hline
\end{tabular}




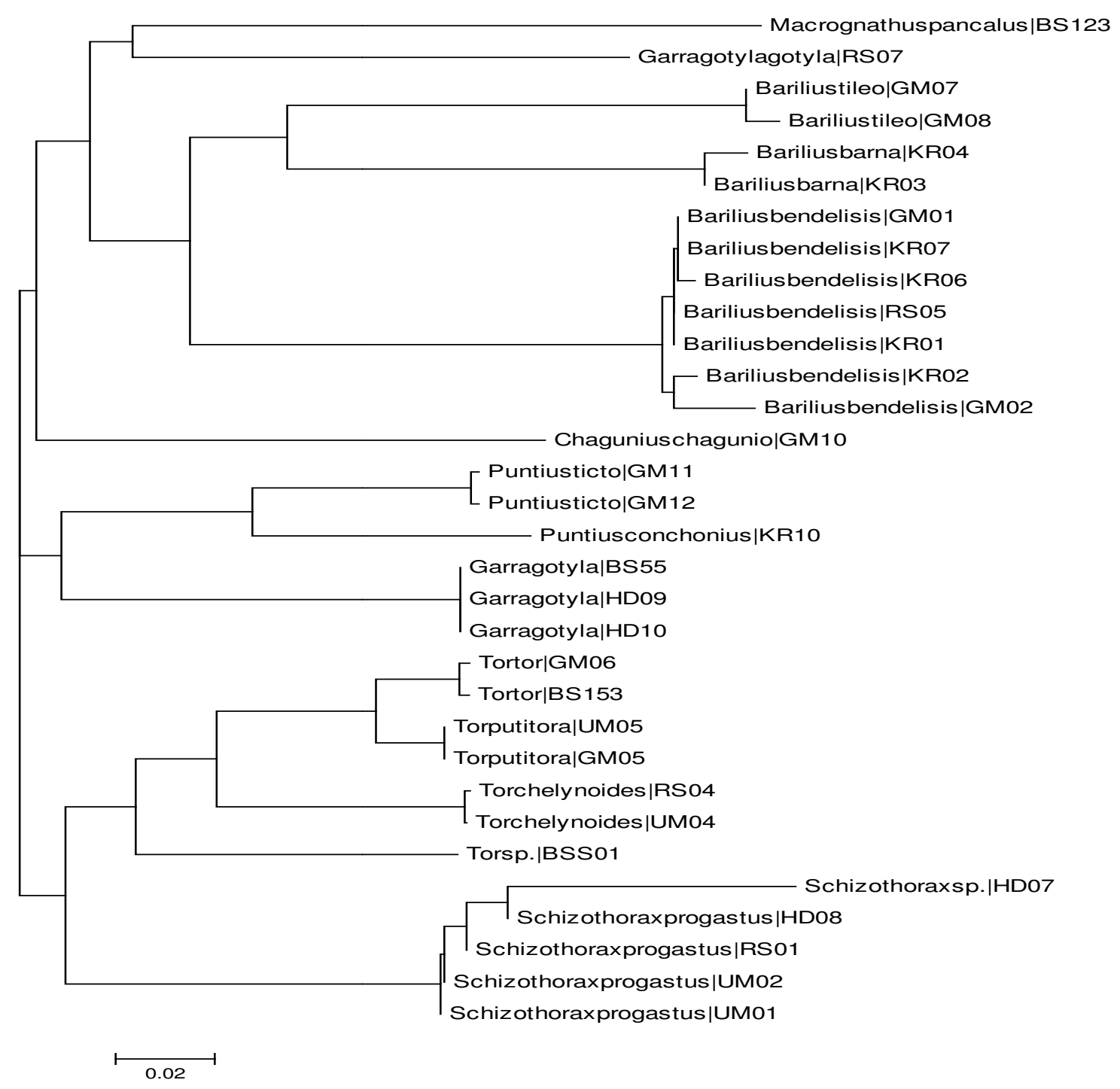

Figure 3: Compact K2P distance (based on NJ tree method) showing 15 analyzed species from the River Song

Table4: Summary of the genetic variability (K2Pdistence) distribution at COI sequences for 50 individuals and 15 species.

\begin{tabular}{|l|c|c|c|c|c|c|c|}
\hline & $\mathbf{n}$ & Taxa & Comparisons & $\begin{array}{c}\text { Min Dist. } \\
(\%)\end{array}$ & $\begin{array}{c}\text { Mean Dist. } \\
(\%)\end{array}$ & $\begin{array}{c}\text { Max } \\
\text { Dist(\%) }\end{array}$ & $\begin{array}{c}\text { SE } \\
\text { Dist(\%) }\end{array}$ \\
\hline Within Species & 26 & 9 & 36 & 0 & $\mathbf{0 . 6 1}$ & 2.1 & 0.02 \\
\hline Within Genus & 30 & 5 & 59 & 3.06 & $\mathbf{1 6 . 3}$ & 23.53 & 0.11 \\
\hline Within Family & 31 & 1 & 370 & 14.87 & $\mathbf{2 1 . 7 9}$ & 33.78 & 0.01 \\
\hline
\end{tabular}



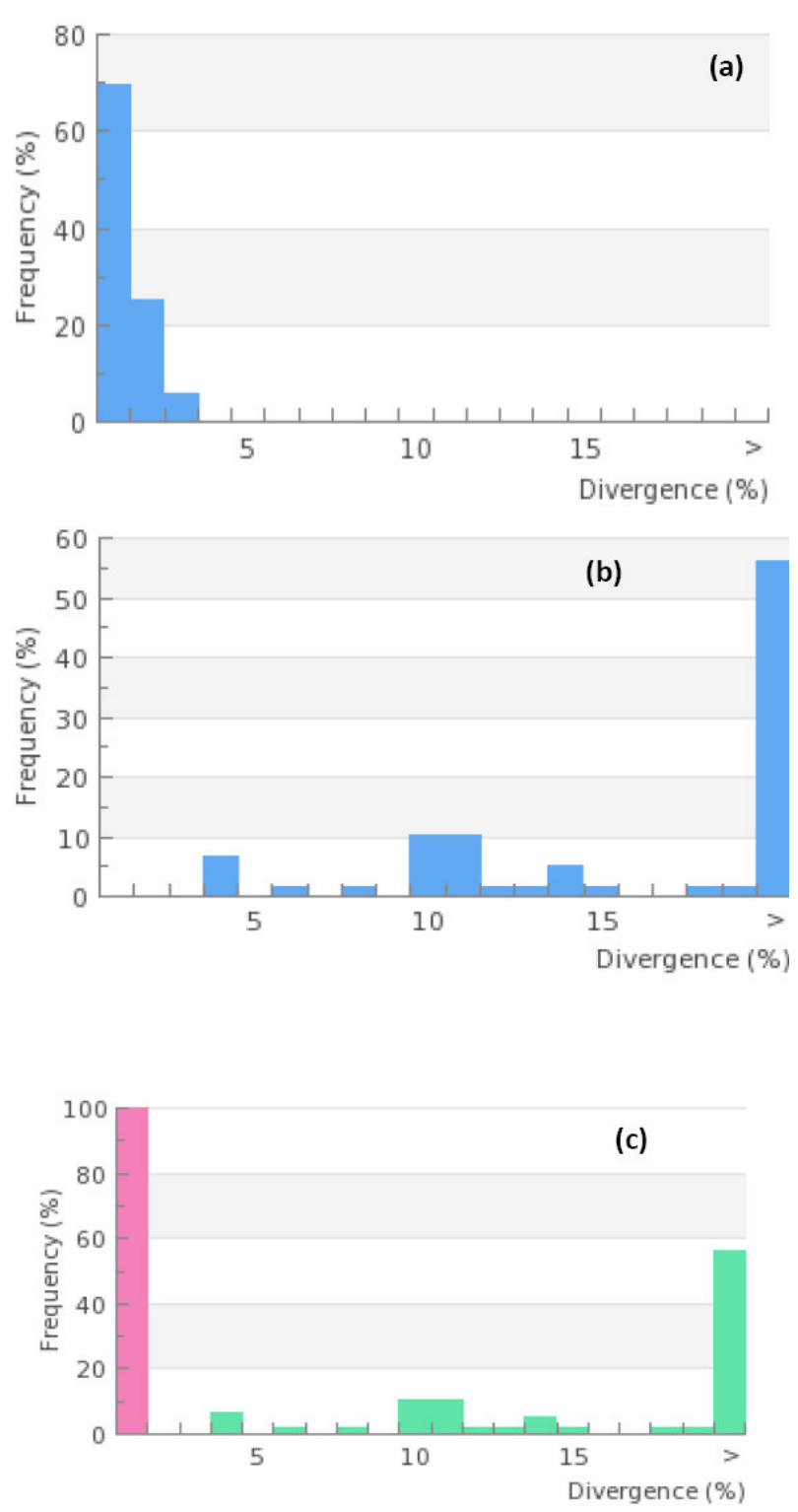

Figure 5. Bold data generated under the project can be seen in following manner for species comparisons. Summary of the genetic variability (K2Pdistences) at COI sequence for 32 individuals and 50 specimens. Sequences divergence at each taxonomic level is summarized as (a) Within species (b) Within genus. (c)The within-species distribution is normalized to reduce bias in sampling at the species level. The table below summarizes this distribution, while the histogram plots the distribution of normalized divergence for species (first column on left) against the genus divergences (all the other columns). (http://www.boldsystems.org/index.php/MAS_Analys is_DistSummary/process)
With the exception of two species (Barilius bandilius and Barilius barna), All species analyzed were monophyletic mean intra-specific distance was less than $1.45 \%$ for $32 \%$ of all species.Mean K2P distance within species genus family, $0.368 \%$, $16.599 \%, 21.985 \%$. In case of Barillius species, the data suggests that there is a higher variation in sequences of COI gene suggesting genetic variations (Fig. 6, 7). Usually individuals of a species are grouped in same place, e.g. in case of Schizothorax species (Fig.7). The data for Barillius species seems to differ from this norm (Fig.6).Cryptic species (look similar but are genetically different) pose a taxonomic challenge as these species cannot be identified easily morphologically. Best way to identify them is through the use of molecular techniques and the best technique available is based on the species specific sequence on particular region of COI gene in mitochondrial DNA. There are a lot fish species in Uttarakhand that inhabit the numerous small streams and rivers and not much is known about their molecular identity. Our study carried out a scan of one such river "River Song" and generated a molecular database base based on DNA barcode (each base in the species specific region of COI is given a colour and hence it is called a Bar Code). Our study identified 15 species from fifty samples belonging to 02 families and their mean divergence was calculated. The most surprising data set was obtained in case of Barillius species (especially Barillius bendelisis). This species is found in almost every small stream of Himalayan region and even in other regions of India. The Barillius species was collected from different location from Song River and even then the tends to show high degree of variability. The sequencing error part for this data was negated by the fact that other samples from other species did not show this variability. Similar data set was obtained for Schizothorax species (Fig. $6 \&$ 7) and the data was analyzed and categorized into a similar group in the phylogenetic tree. However all the samples were assigned a different position in phylogentic tree in case of Barillius (Fig 6). Barilius barna and Barilius bandilius are morphologically similar and sometimes it is difficult to differentiate them on physical basis. They were clearly identified by the molecular dataset and both the species were categorized into two separate sections (Fig. 3). 
Thapliyal et al.

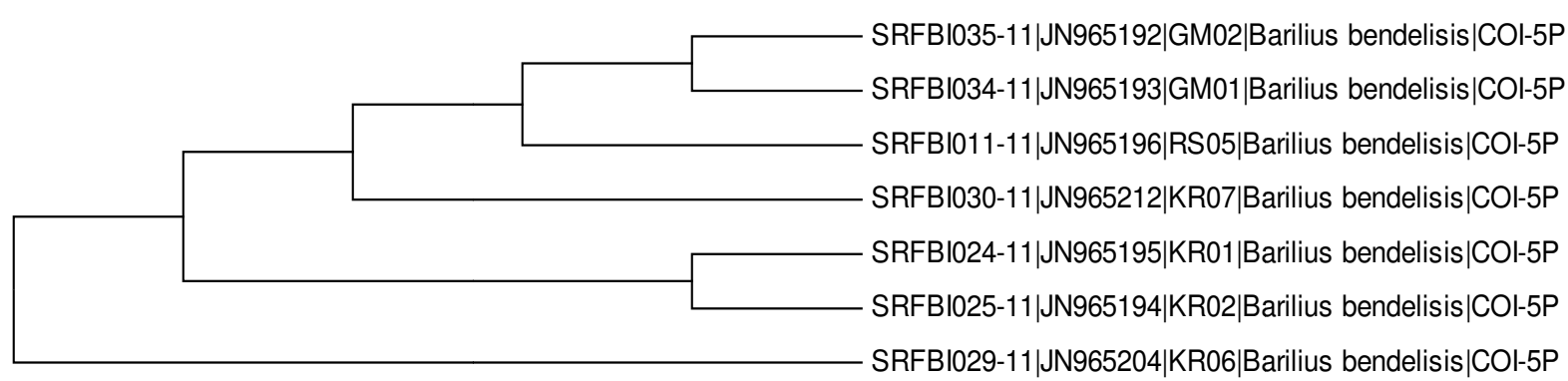

Phylogenic Tree Construction of Barillus bendelisis species of Song River

Figure 6: K2P distance (generated using NJ tree method) of Barillus bendelisiswith high con-specific genetic divergence. Voucher numbers are indicated before species name. Phylogeny among Barilius bendelisis sample in voucher ID GM02 (first sample in figure) is suggestively different to Barilius bendilius voucher ID KR06 (last sample in figure).

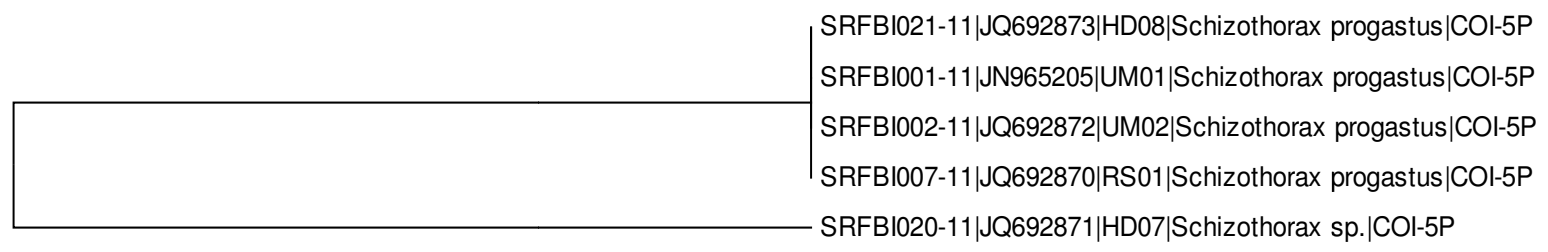

\section{$\longmapsto .001$}

Figure 7: K2P distance (generated using NJ tree method) of Schizothorax species. Voucher numbers indicated before species name. Schizothorax species are mostly clustered together and do not show much variations among similar populations.

Overall the genetic mean distance between conspecific $(0.61 \%)$ and con-generics $(16.3 \%)$ for the song river fishes (Table-4 and Fig. 5)were higher than the previously reported in the marine (0.3 and $8.4 \%$; (Ward et al. 2009) and or fresh water ecosystem 0.45/5.1\%;Hubert et al.(2008).The average K2P divergence within con-specific specimens was only $0.61 \%$ a value $30 \%$ (approximately)time lower than the found among congeneric species (16.3\%).These values are consistent with those found in the literature. Ward et al. (2005) found average value of 0.39 and $9.93 \%$ by cons specific and congeneric comparisons, respectively for marine fishes, discriminating all species.Hubert et al (2008), studying freshwater fishes from Canada ,found average K2P values of $0.27 \%$ (con-specific) and $8.37 \%$ congeneric, discriminating $93 \%$ of the species.While Word et al.(2009) analyzed the values of K2P genetic divergence of 108 fish species available on BOLD and found the K2P valves of $0.3 \%$ (con-specific) and $8.4 \%$ congeneric ,discriminating about $97.5 \%$ of the species .these values are very similar with those found in the present study.Thedifference between con-specific and congeneric average K2P divergence was more pronounced in our analysis 30\% (approximately) fold difference compared with values found in other fish species .Analysis of 32 barcode sequence belonging to 50 aquatic species under phylum chordate showed that BOLD is well suited to the identification of biological organisms at different taxonomic level. Our analyses, based on the mitochondrial genes COI-1 are capable of discriminating cold water species with high accuracy. A total of $32 \mathrm{COI}$ barcode of $656 \mathrm{bp}$ were thus obtained for 15 species .nucleotide composition showed a CT bias within $\mathrm{C}=27.49, \mathrm{~T}=29.29, \mathrm{~A}=25.28, \mathrm{G}=17.88$, sequence have been deposited in Gene Bank (Accession no in table 3). Accession numbers for the barcodes, and collection data, sequence, trace file and primers details were available in NCBI gene bank.In our present study 15 species were well resolved by 
DNA barcoding using COI gene. Phylogenetic tree is also showing the species packing in resemblance with taxonomic hierarchies. It proves the authenticity of DNA barcoding using COI gene as shown in previous cases. All data generated under this research work can be accessed using internet resources using BOLD web page. (www.boldsystem.org). COI based species identification data shows that river is having15 species. A very high variation in sequences of COI from Barillius species was a surprise. It will be a matter of further studies to assess and investigate these variations.

\section{Acknowledgement}

Sincere thanks to State Biotechnology Program (SBP), Govt. of Uttarakhand for financial assistance. Sequencing was carried out at Department of Zoology, Baba Sahib BheemraoAmbedkarMarathwada University, Aurangabad.

\section{References}

Aron, S.L., and Sole-Cava, A.M., 1991. Genetic evaluation of the taxonomic status of two varietiesof the cosmopolitan ascidian Botryllus niger (Ascidiaceae: Botryllidae). Biochem Syst Ecol., 19:271-276.

Diwakar, S. and Balakrishnan, R., 2007. Vertical stratification in an acoustically communicating ensiferan assemblage of a tropical evergreen forest in southern India. Journal of Tropical Ecology, 23: 479-486.

Chakrabarty, P., 2010. Genetypes: a concept to help integrate molecular systematics and traditional taxonomy. Zootaxa, 2632:67-68.

Gusmão, J., Lazoski, C. and Solé-Cava, A.M., 2000. A new species of Penaeus (Crustacea: Penaeidae) revealed by allozyme and citochrome oxidase I analyses. Mar. Biol., 137:435-446.

Hajibabaei, M., Singer G. A.C., Hebert, P. D.N. and Donal, A. H. 2007. DNA barcoding: how it complements taxonomy, molecular phylogenetics and population genetics. Trends Genet.;23(4):167-72.

Hebert, P.D.N., Cywinska, A., Ball, S.L. and Waard,De J.R., 2003. Biological identifications through DNA barcodes. Proc. R. Soc.B., 270: 313-322. (doi:10.1098/rspb.2002. 2218.)

Hubert, N., Hanner, R, Holm, E, Mandrak N.E, Taylor, E, Burridge, M, Watkinson, D, Dumont, P, Curry, A, Bentizen, P, Zhang, J, April, J, Bernatchez, L. 2008.
Identifying Canadian fresh water fishes through DNA Barcodes. PLos ONE 3:e2490.

http://www.boldsystems.org/index.php/MAS_Analysis_DistSu mmary/process

Ivanova, N.V., Zemlak, T.S., Hanner, R.H. and Hebert P.D.N. 2007. Universal primer cocktail for fish DNA Barcoding. Mol. Ecol. Notes., 7:544-548.

Lemer S, Aurelle D, Vigliola L, Durand JD, Borsa P. 2007. Cytochrome b barcoding, molecular systematics and geographicdifferentiation in rabbitfishes (Siganidae). $\boldsymbol{C} \boldsymbol{R}$ Biol. 330:86-94.

Lumbsch, H.T. and Leavitt, S.D., 2011. Goodbye morphology? A paradigm shift in the delimitation of species in lichenized fungi. Fungal diversity, 50(1):59-72. DOI:10.1007/s13225-011-0123-z.

Manwell, C. and Baker, C.M.A., 1963. A sibling species of seacucumber discovered by starch-gel electrophoresis. Comp. Biochem. Physiol. 10:39-53.

Mendonca, F.F., Hashimoto, D.T., Forto-Foresti, F., Oliveira, C., Gadig, O.B.F. and Foresti, F. 2009. Identification of Shark species Rhizopriondon lalandii and $R$. porosus (Elasmobranchii, Carcharhinidae) by multiplex PCR and PCR-RFLP techniques.Mol-Ceol Resour, 9(3):771-773

Moyse's, C.B. and Almeida-Toledo L.F. 2002. Restriction fragment lengthpolymorphisms of mitochondrial DNA among five freshwaterfish species of the genus Astyanax (Pisces, Characidae).Genet. Mol. Biol. 25:402-407.

Pfenninger, M., Nowak, C., Kley,C., Steinke, D.and Streit, B. 2007. Utility of DNA taxonomy and barcoding for the inference of larval community structure in morphologically cryptic Chironomus (Diptera) species. Molecular Ecology, 16:1957- 1968.

Pook, C. E. and McEwing, R. 2005. Mitochondrial DNA sequences fromdried snake venom: A DNA barcoding approach to theidentification of venom samples. Toxicon, 46:711-715.

Pyke, G.H. and Ehrlich, P.R., 2010. Biological collections and ecological/environmental research: a review, some observations and a look to the future. Biological Reviews 85: 247-266.

Shaffer, H.B. and Thonsom, R.C. 2007. Delimiting species in recentradiations. Syst. Biol.56:896-906.

Ward, R.D. 2009. DNA barcode divergence within species andgenera of birds and fishes. Mol. Ecol. Resour. 9:1077-1085.

Ward, R.D., Zemlak, T.S., Innes, B. H., Last, P.R, Hebert P.D.N. 2005.DNA barcoding Australia's fish species. Philos. Trans. R. Soc. B. Biol. Sci.360:1847-1857. 